\title{
ŁÓDŹ W PRACACH MAGISTERSKICH STUDENTÓW KIERUNKU GEOGRAFICZNEGO SPECJALIZACJI GEOGRAFIA TURYZMU NA UNIWERSYTECIE ŁÓDZKIM
}

\author{
LA VILLE DE ŁÓDŹ DANS LES THĖSES DE MAÎTRISE
}

DES ÉTUDIANTS DE GÉOGRAPHIE SE SPÉCIALISANT DANS LA GÉOGRAPHIE DU TOURISME À L'UNIVERSITÉ DE ŁÓDŹ

\section{LODZ IN THE M.A.S WRITTEN BY STUDENTS \\ OF THE GEOGRAPHY OF TOURISM AT THE DEPARTMENT \\ OF GEOGRAPHY, UNIVERSITY OF LODZ}

W 1998 r. mija 14 lat od obrony pierwszej pracy magisterskiej napisanej na seminarium magisterskim specjalizacji ,geografia turyzmu” Uniwersytetu Łódzkiego. W tym roku została obroniona ostatnia praca magisterska na tej specjalizacji, która z dniem 30 września zakończyła swoją działalność. W ciągu 16 lat funkcjonowania specjalizacji z geografii turyzmu przedstawiono do recenzji i obroniono 176 prac magisterskich. Ich tematyka była bardzo szeroka i różnorodna, bowiem obejmowała ocenę walorów fizycznogeograficznych i antropogeograficznych na potrzeby turystyki, badania atrakcyjności regionów, miejscowości i obiektów turystycznych, analizę funkcji turystycznej, zagospodarowania, ruchu turystycznego, osadnictwa turystycznego, a także zagospodarowania wolnego czasu oraz wypoczynku różnych grup społeczno-demograficznych i zawodowych (tematykę prac szczegółowo opisał S. Liszewski w niniejszym zeszycie, s. 117-127). Studenci wybierali do badań zwykle tereny miejsca swojego zamieszkania, obszary, na których spędzali wakacje w dzieciństwie, a także miejscowości lub regiony poznane podczas studiów w trakcie ćwiczeń terenowych czy podróży wakacyjnych. Penetracji badawczej łódzkich studentów specjalizacji z geografii turyzmu podlegały niemal wszystkie regiony Polski. Łódź, mimo łatwego dla studentów Uniwersytetu Łódzkiego dostępu jako terenu badań, nie była z początku obiektem zainteresowań adeptów geografii turyzmu. Przez pierwsze osiem lat, statystycznie ujmując, zaledwie jeden student w ciagu roku podejmował badania w zakresie szeroko rozumianej turystyki na obszarze Łodzi. Dopiero w latach 1994-1997 nastapił wzrost zainteresowania miastem, w którym studiują, w wyniku czego w tym okresie powstało aż 23 z 31 wszystkich prac magisterskich dotyczących turystyki i wypoczynku na terenie Łodzi. 
Zainteresowanie to pojawiło się wraz z wyraźnie postępującym kreowaniem Łodzi jako miasta identyfikowanego $\mathrm{z}$ funkcją turystyczna, $\mathrm{z}$ nastawieniem na specjalną grupę turystów, tzw. turystykę sentymentalną. Łódź bowiem, jako miasto trzech narodowości (polskiej, żydowskiej i niemieckiej) w XIX i na początku XX w., zachowała wiele ciekawych obiektów z tego okresu, które coraz częściej przyciagają tu potomków byłych właścicieli fabryk lub mieszkańców tego miasta. Znajdują się tu bardzo interesujące przykłady reprezentujące zarówno budownictwo industrialne, związane $\mathrm{z}$ dominującym w przeszłości przemysłem włókienniczym (zespoły fabryczno-rezydencjonalne I. Poznańskiego, K. Scheiblera itd.), jak i dobrze zachowane nekropolie z tego okresu, w tym największy w Europie cmentarz żydowski, oraz świetnie zachowana architektura eklektyczna ulicy Piotrkowskiej z unikatowymi przykładami architektury secesyjnej.

W ostatnich latach pojawiły się też ogromne możliwości Łodzi w zakresie obsługi uczestników licznych konferencji naukowych i branżowych oraz organizowanych coraz częściej różnego rodzaju targów.

Nowy obraz Łodzi z punktu widzenia turystyki, który wyłonił się dopiero w drugiej połowie lat dziewięćdziesiątych, zainspirował i zachęcił studentów specjalizacji ,geografia turyzmu” do podejmowania badań na terenie miasta.

Najwięcej prac magisterskich (14) poświęcono analizie funkcji turystycznej lub kulturalno-wypoczynkowej oraz wartości turystyczno-kulturalnej różnych obiektów Łodzi. W grupie tej znalazły się trzy popularne parki rekreacyjne: Park Kultury i Wypoczynku (K r ó la k 1985), park im. A. Mickiewicza (G nat owski 1996) oraz Las Łagiewnicki (B u r zy k 1993). W pracach tych omówiono walory środowiska badanego obiektu, jego zagospodarowanie, a także dostępność komunikacyjną. W dalszej części poddano charakterystyce społeczno-demograficznej oraz terytorialnej wypoczywających na obszarach badanych parków oraz przedstawiono formy wypoczynku i dynamikę ruchu wypoczynkowego. Dokonano również oceny znaczenia parków w aspekcie potrzeb wypoczynkowych mieszkańców miasta, a także ochrony środowiska.

W grupie prac dotyczących funkcji turystycznej znalazły się także dwa opracowania poświęcone hotelom łódzkim: Funkcja turystyczna tódzkiego oddzialu PBP „Orbis" Sp. z o.o. i hotelu Grand Orbis s.a. w Łodzi (D e l ą g 1996) oraz Funkcja turystyczna hoteli lódzkich na przykladzie hoteli PT „Łódź” (B i e $\mathrm{n}$ i e k 1994). Są to obszerne monografie dwóch największych w Łodzi przedsiębiorstw turystycznych, z rozbudowaną częścią poświęconą ich działalności w zakresie hotelarstwa. Znalazły się tu szczegółowe charakterystyki techniczno-ekonomiczne hoteli oraz informacje nt. ich wykorzystania. Przeanalizowano również przemiany $w$ funkcjonowaniu hoteli pod wpływem wprowadzonej w Polsce gospodarki rynkowej, przedstawione na tle wyników badania ruchu turystycznego. W końcowej części pracy zaprezentowano perspektywy dalszego rozwoju hoteli łódzkich znajdujących się w gestii badanych przedsiębiorstw. 
Tematem kolejnych prac magisterskich była funkcja kulturalno-wypoczynkowa. Pierwsza tego rodzaju praca dotyczyła łódzkich kin ( $\mathrm{N} \mathrm{u} \mathrm{r} \mathrm{c} \mathrm{z} \mathrm{y} \mathrm{ń} \mathrm{s} \mathrm{k} \mathrm{i}$ 1993), w której określenie tej funkcji poprzedzono krótkim omówieniem historii kina, lokalizacji kin w mieście, form ich funkcjonowania, a także oceną ich atrakcyjności kulturalno-wypoczynkowej. Szczegółowej analizie poddano użytkowników kina - widzów, badając ich strukturę demograficzno-społeczną, miejsce zamieszkania, motywy korzystania $\mathrm{z}$ tego rodzaju usług kulturalnych i motywy wyboru kina. W konsekwencji przeprowadzonych badań podjęto ocenę wyposażenia Lodzi w ten typ placówek kulturalnych oraz poziomu ich usług.

Podobne badania przeprowadzono w łódzkich pałacach pofabrykanckich (M a t y s i a k 1996), przedstawiając najpierw historię ich powstania, architekturę zespołów pałacowych, a następnie organizowane w nich imprezy kulturalne i ekspozycje. W dalszej części pracy poddano analizie korzystających z usług kulturalnych świadczonych przez placówki muzealne zlokalizowane w omawianych pałacach. Badano strukturę demograficzno-społeczną, miejsce zamieszkania, częstotliwość korzystania z poszczególnych obiektów, sezonowość, a także motywy odwiedzania tego rodzaju obiektów. W efekcie dokonano oceny poziomu i zakresu pełnionych przez badane pałace funkcji turystyczno-kulturalnych.

Określeniu funkcji turystyczno-kulturalnej łódzkich muzeów (S t e p c z u k 1997) poświęcono inną pracę, w której, po dokonaniu charakterystyki muzeów w Lodzi, poddano analizie ruch turystyczny - jego formy i wielkość, sezonowość, ruch w ciągu tygodnia oraz strukturę społeczno-demograficzną odwiedzających muzea $\mathrm{i}$ ich pochodzenie terytorialne, aby w efekcie określić zasięg ich oddziaływania oraz funkcję turystyczno-kulturalną tych placówek.

Kolejne prace magisterskie dotyczyły oceny wartości turystycznej wybranych do badań obiektów Łodzi. Jedna dotyczyła zespołu fabryczno-rezydencjonalnego Karola Scheiblera „Księży Młyn” (S z a r k o 1997), a druga jurydyki Izraela Poznańskiego (T o m c z y k 1997). W pracach tych, po uprzedniej charakterystyce obiektu $z$ uwzględnieniem położenia, historii, architektury oraz dostępności komunikacyjnej, szczegółowej analizie poddano społeczno-demograficzne cechy oraz pochodzenie terytorialne osób odwiedzających obiekt. Omówiono ruch turystyczny na terenie obiektu, a także przeprowadzono badania percepcyjne wśród ankietowanych turystów oraz wśród mieszkańców Łodzi. Przedstawiono także opinie ekspertów na temat użyteczności krajoznawczej i kulturalnej badanych obiektów oraz, na końcu pracy, propozycje wykorzystania ich na potrzeby turystyki.

Dokonując $w$ innej pracy oceny wartości turystycznej ulicy Piotrkowskiej (C i c ho ń s k a 1995) skupiono uwagę najpierw na jej walorach architektonicznych oraz na określeniu miejsca tej ulicy we współczesnej organizacji społecznej i funkcjonalnej miasta. Przeprowadzono również badania percepcji Łodzi przez reprezentantów różnych grup społeczno-zawodowych jej mieszkańców 
- studentów geografii turyzmu, nauczycieli wybranych szkół, a także uczestników wybranych edycji łódzkich targów, czyli osób wizytujących Łódź. Na podstawie waloryzacji badanego obszaru oraz analizy uzyskanych opinii określono wyniki kształtujące wartość turystyczną ulicy Piotrkowskiej.

W ramach omawianego seminarium powstała jeszcze jedna praca magisterska podejmująca ocenę wartości turystycznej, w której przedmiotem badań była Łódź, a oceny tej wartości dokonali jej mieszkańcy (W i t k o w s k a 1995). Podobnie jak w poprzednich dwóch pracach, wykorzystano również metodę badań percepcyjnych, dzięki której sporządzono waloryzację przestrzeni turystycznej Lodzi i wskazano atrakcyjne i nieatrakcyjne miejsca na terenie miasta w opinii jego mieszkańców. W opracowaniu tym dokonano także oceny znajomości miasta przez jego mieszkańców, a także przyjrzano się promocji turystycznej Lodzi, z uwzględnieniem promocji wewnętrznej i zewnętrznej ogólnopolskiej i zagranicznej.

Inny charakter miała praca, w której ocenę wartości Łodzi przedstawiono na podstawie analizy przewodników turystycznych ( $\dot{Z}$ e b r o w s k a 1996). Do badań wykorzystano tu przewodniki polskie po Lodzi ( 9 publikacji), przewodniki polskie po Polsce (5) oraz przewodniki zagraniczne po Polsce (5) - obcego autorstwa $\mathrm{i}$ wydawnictwa. Oceny obrazu turystycznego miasta dokonano na podstawie charakterystyki liczby prezentowanych $\mathrm{w}$ przewodnikach obiektów oraz treści. Uzyskane wyniki posłużyły do wyznaczenia klas popularności obiektów i wskazaniu w przestrzeni miasta stref kreujących jego obraz turystyczny. W wyniku przeprowadzonej analizy stwierdzono brak możliwości jednoznacznego określenia wartości turystycznej Łodzi w świetle opublikowanych dotąd przewodników, wobec czego autorka przedstawiła własny projekt przewodnika po Łodzi.

W jednej z prac magisterskich zaprezentowano ocenę łódzkiego ośrodka jako miejsca organizacji kongresów, konferencji i seminariów naukowych (Bła s z c z y k 1997). Po dokonaniu przeglądu placówek organizujących konferencje naukowe w Lodzi, przedstawiono imprezy, które odbyły się w latach 1995-1996, określając ich rodzaj, czas trwania, liczbę uczestników i udział gości spoza miasta. Na tej podstawie określono zasięg przestrzenny oddziaływania Łodzi jako ośrodka konferencyjnego oraz sezonowość i częstotliwość odbywających się tego typu imprez. Dokonano inwentaryzacji ośrodków konferencyjnych oraz bazy noclegowej i gastronomicznej wykorzystywanej do ich obsługi. W efekcie przeprowadzonych badań przedstawiono korzyści płynące dla Łodzi z tytułu organizowania na jej terenie konferencji naukowych i ukazano perspektywy dalszego rozwoju tej funkcji w mieście.

14 przedstawionych prac magisterskich dotyczyło, najogólniej mówiąc, elementów krajoznawczych Łodzi i funkcji turystycznych obiektów. Kolejną grupę stanowią organizatorzy turystyki i wypoczynku mieszkańców miasta. 
Trzy prace z tej grupy poświęcone były wybranej działalności biur turystycznych w Łodzi.

Pierwszym przykładem może być praca pt. Funkcja poznawcza wycieczek szkolnych organizowanych przez biuro turystyczne "Panorama” (D e n y s - S k u p i eń s k a 1997). Zajmując się w niej tylko jedną z form działalności biura, autorka przeprowadziła uprzednio ogólną charakterystykę biura, koncentrując się na strukturze jego działalności oraz zasięgu przestrzennym. Omówiła ofertę wycieczek szkolnych krajowych i zagranicznych w sezonie 1996 r. i jej wykorzystanie, a także przedstawiła istotę, genezę i klasyfikację tych wycieczek oraz rolę krajoznawstwa w kształceniu postaw dzieci i młodzieży. Na zakończenie określiła stopień zaspokojenia potrzeb turysty przez badane biuro oraz dokonała oceny jego obshugi.

Kolejnym przykładem analizy działalności biura turystycznego jest praca pt. Weryfikacja zagraniczna oferty turystycznej PT ,Grand Tour” w sezonie letnim 1994 r. przez mieszkańców Łodzi (R o g a ls k i 1995). Po przedstawieniu rodzaju i zakresu działalności „Grand Touru”, a także wielkości nakładów, wachlarza oferowanych świadczeń itd., dokonano charakterystyki respondentów, motywów wyboru tego konkretnego biura i częstotliwości „wyjazdów z nim" oraz określono i oceniono poziom oferowanych usług, pracę pilotów oraz ogólny poziom organizowanych przez "Grand Tour” imprez zagranicznych. W pracy tej podstawą oceny pracy biura był odbiór jego działalności przez klientów, co uzyskano dzięki zastosowaniu metody percepcyjnej.

Działalność biura turystycznego jako organizatora turystyki i wypoczynku mieszkańców Lodzi przedstawiono w pracy dotyczącej PT „Łódź” Centrum Usług Turystycznych (K o ł o d z i e j c z y k 1997). W pracy magisterskiej na ten temat, będącej monografią biura, autor szeroko omówił jego strukturę organizacyjną i zakres działalności, a także dokonał szczegółowej charakterystyki korzystających z usług PT „Łódź”, przedstawiając w konsekwencji ocenę możliwości dalszego rozwoju i działalności jednego z większych i ważniejszych biur w mieście.

Przedmiotem zainteresowań jednej ze studentek były także wyjazdy zagraniczne łodzian (S a 1 t a r s k a 1991). Po omówieniu specyfiki miasta i dokonaniu charakterystyki jego mieszkańców autorka przedstawiła 10 wybranych do badań biur podróży w Łodzi. Prezentując ich działalność zagraniczną skupiła się na wielkości ruchu wyjazdowego, kierunkach, sezonowości i formach wyjazdów zagranicznych realizowanych za pośrednictwem poszczególnych biur turystycznych Łodzi. Omówiła także środki transportu oraz bazę noclegową i żywieniową wykorzystywaną przez biura podróży. W dalszej części autorka dokonała analizy społeczno-demograficznej i zawodowej osób korzystających z tego rodzaju usług. Na podstawie przeprowadzonych badań określono ekonomiczne i socjologiczne aspekty turystycznych wyjazdów zagranicznych łodzian, motywy ich wyjazdów, a także czynniki decydujące o wyborze usług danego biura. Uchwy- 
cone zostały także zmiany i tendencje w zagranicznej turystyce wyjazdowej mieszkańców Łodzi w okresie poprzedzającym zmiany społeczno-ekonomiczne w Polsce.

Dwie $\mathrm{z}$ obronionych prac magisterskich $\mathrm{w}$ ciagu czasu funkcjonowania w UŁ specjalizacji z geografii turyzmu poświęcone były turystyce kwalifikowanej mieszkańców Łodzi.

Jedna praca $\mathrm{z}$ tej dziedziny poświęcona była wędkarstwu (L e w a n d owski 1993). Autor poddał analizie tych mieszkańców Łodzi i innych miast aglomeracji łódzkiej, którzy jako formę wypoczynku preferują wędkarstwo. Po dokonaniu charakterystyki terenów wędkarskich w Polsce oraz omówieniu działalności Polskiego Związku Wędkarskiego w okręgu łódzkim, przedstawiono wyniki badań empirycznych nad wędkarstwem jako formą spędzania wolnego czasu przez mieszkańców aglomeracji łódzkiej, w tym sezonowości, częstotliwości wyjazdów, preferencji wyboru miejsca wyjazdu w okresie wakacyjnym i weekendowym. Na podstawie uzyskanych wyników dokonano oceny atrakcyjności Polski, jako terenu uprawiania turystyki wędkarskiej w opinii osób preferujących ten sport.

W drugiej z prac magisterskich dotyczących turystyki kwalifikowanej przedmiotem badań były ośrodki jeździeckie jako tereny turystyczne i rekreacyjne dla mieszkańców Łodzi i okolic (C z a p l i ń s k i 1996). Na wstępie omówiono atrakcyjność turystyczno-wypoczynkową trzech wybranych ośrodków jeździeckich, dokonując ich charakterystyki fizycznogeograficznej oraz przedstawiając ich lokalizację, historię i cechy zabudowy. Zbadano wielkość ruchu wypoczynkowego, częstotliwość oraz sezonowość korzystania z ośrodków jeździeckich, a także motywy wyboru tej formy i miejsca wypoczynku. Dokonano też charakterystyki społeczno-demograficznej wybierających ten sposób spędzania czasu wolnego oraz przeanalizowano ich miejsca zamieszkania, aby w konsekwencji tych badań określić tzw. pola rynkowe, czyli tereny Łodzi wyróżniające się największym zainteresowaniem tego typu wypoczynkiem.

Kolejna grupa tematów podejmowanych w pracach magisterskich przez studentów geografii turyzmu UŁ dotyczy wykorzystania terenów rekreacyjnych w Lodzi przez jej mieszkańców. Reprezentują ją prace Miejski Ośrodek Sportu i Rekreacji jako tereny wypoczynku letniego mieszkańców Łodzi na przykładzie Stawów Stefańskiego i Stawów Jana (N i e d ź w i e c k a 1994) oraz Miejski Ośrodek Sportu i Rekreacji „,Malinka” jako obszar wypoczynku dla mieszkańców Lódzkiej Aglomeracji Miejskiej (L e s s m a n 1994). Po dokonaniu fizycznogeograficznej charakterystyki badanych terenów przedstawiono w nich szczegółowo walory rekreacyjne, zagospodarowanie, dostępność komunikacyjną oraz ruch wypoczynkowy, z uwzględnieniem jego cech demograficzno-społecznych i zasięgu przestrzennego w celu określenia atrakcyjności wypoczynkowej badanych obiektów rekreacyjnych dla łodzian. 
Dużą grupę prac magisterskich (9) adepci geografii turyzmu UŁ poświęcili wypoczynkowi różnych grup demograficzno-spolecznych i zawodowych mieszkańców Łodzi.

W czterech pracach przebadano wybrane grupy społeczno-zawodowe: pracowników ZPDz. „Olimpia” (S z c z e g i e l s k a 1989), pracowników ŁZPB im. Obrońców Pokoju „Uniontex” (G w a d e r a 1996), rzemieślników łódzkich (K e g l e r 1990) i uczniów XXV LO (W a l b o r s k a 1995). Po krótkim omówieniu działalności wybranych do badań zakładów i instytucji oraz charakterystyce demograficzno-społecznej ich pracowników, szczegółowej analizie demograficznej, społecznej, zawodowej i ekonomicznej poddano grupę ankietowanych. Każdorazowo wykonano bilans wykorzystania czasu wolnego (urlopowego i sobotnio-niedzielnego), przenanalizowano geograficzne rozmieszczenie wyjazdów, zbadano formy i sezonowość wyjazdów, a także przyczyny nie korzystania z urlopów. Omówiono także organizację wypoczynku weekendowego i urlopowego macierzystych zakładów pracy. W efekcie badań uzyskano obraz preferencji wypoczynkowych różnych grup społecznych, demograficznych i zawodowych mieszkańców Lodzi.

Cztery prace dotyczą wypoczynku mieszkańców osiedli łódzkich, w tym: osiedla im. Stefana Batorego (M i ązek-K a jk ow ska 1988), Starych Chojen ( $\mathrm{Z}$ m y sło w s a 1994), osiedla Radogoszcz Zachód (S z y m a ń s k a 1995) oraz osiedla „Pojezierska” (M i c h a l a k 1998). W przypadku tego rodzaju prac, po dokonaniu ogólnej charakterystyki geograficzno-historycznej osiedla oraz omówieniu cech społeczno-demograficznych i zawodowych mieszkańców, przystapiono do badań wybranej, zwykle losowo, grupy osób. Szczegółowej analizie poddano trzy rodzaje wypoczynku rozróżniane ze względu na długość czasu wolnego od pracy zawodowej: wakacyjno-urlopowy, weekendowy oraz wypoczynek codzienny (w mieście). Sporządzano też bilans czasu wolnego i jego wykorzystanie wg form, miejsc, kierunków, długości pobytów, sezonowości i sposobów spędzania czasu. Zaproponowano również model turystyki i wypoczynku badanej grupy społecznej (S z y m a ń s k a 1995).

Jedna praca magisterska została poświęcona wycieczkom organizowanym przez zakłady pracy jako formom wypoczynku mieszkańców Łodzi (P a w l a k 1990). Po omówieniu 160 wybranych do badań łódzkich zakładów pracy, reprezentujących wszystkie działy gospodarki narodowej, przeanalizowano oferty zakładowych świadczeń socjalnych i omówiono organizowane wycieczki (turystyczno-krajoznawcze i grzybobrania), uwzględniając kierunki wyjazdów, czas trwania, formy oraz sezonowość.

Przegląd prac magisterskich dotyczących Łodzi z zakresu szeroko rozumianej turystyki ukazuje rozległość tematyczną, różnorodność podejść i stosowanych metod badawczych przez absolwentów uczelni znajdującej się w mieście powszechnie nie identyfikowanym z funkcją turystyczną. 31 prac poświęconych Łodzi (ok. 18\% wszystkich bronionych prac magisterskich dotyczących turys- 
tyki), często o bardzo wysokim poziomie merytorycznym z dużym ładunkiem faktów potwierdzających teorie, świadczy o możliwościach i szansach, jakie stoja przed tym miastem, a przede wszystkim potwierdza słuszność funkcjonowania przez 16 lat specjalizacji z geografii turyzmu w Lodzi.

Dokonując przeglądu tematycznego prac magisterskich dotyczących problematyki szeroko ujętej turystyki na terenie Łodzi, należy zwrócić uwagę, że praktycznie po raz pierwszy w takiej skali i w tak szerokim zakresie zostały przeprowadzone badania naukowe nad turystyką w tym mieście. Istniejące dotychczas informacje o walorach turystycznych Łodzi pochodzą głównie z przewodników turystycznych, które z natury rzeczy mają charakter opracowań kompilacyjnych. Wszystkie omawiane prace magisterskie opierają się natomiast na wynikach konkretnych, empirycznych badań turystycznych, przeprowadzonych przez studentów, co nie tylko wzbogaca naszą wiedzę o tym mieście, ale daje zupełnie nowe spojrzenie na wiele spraw.

Przeprowadzone w pracach magisterskich badania, najogólniej rzecz ujmując, przedstawiły w nowym świetle wiele obiektów i obszarów turystycznych Łodzi, podnosząc nie tylko ich specyfikę czy oryginalność, ale także dostępność dla turystyki oraz ukazując ich rangę w krajowym i międzynarodowym ruchu turystycznym.

Drugi generalny wniosek płynący z tych badań dotyczy pełnego rozeznania w różnych przekrojach terytorialnych (osiedla), jak i społecznych - form, sezonowości i miejsc wypoczynku mieszkańców Łodzi w okresie wakacji i urlopów. Jest to ważny zbiór informacji umożliwiający zrozumienie zachowań turystycznych łodzian, a także określający poziom warunków życia mieszkańców miasta.

Wreszcie, trzeci generalny wniosek dotyczy samych badań, prowadzonych przez magistrantów na potrzeby ich prac, i łączy się z postrzeganiem Łodzi jako miasta turystycznego zarówno przez przybyszów, jak i mieszkańców. Były to bardzo cenne badania, dające przynajmniej częściową odpowiedź na pytanie, na ile Łódź może już dziś być uznana za miasto turystyczne.

Wymienione trzy grupy wyników uzyskanych w pracach magisterskich przygotowywanych na specjalizacji z geografii turyzmu układają się w pewną logiczną całość turystycznego programu badań Łodzi. Dotyczą one bowiem potencjału turystycznego Łodzi i jego użytkowania (funkcji turystycznej), potrzeb wypoczynkowych mieszkańców miasta oraz postrzegania Łodzi jako miasta turystycznego.

\section{PIŚMIENNICTWO}

B i e n i e k J., 1994, Funkcja turystyczna hoteli łódzkich na przykladzie hoteli Przedsiębiorstwa Turystycznego „Lódz””, praca magisterska, Katedra Geografii Miast i Turyzmu UŁ.

B ł a s z c z y k J., 1997, tódź jako miejsce organizacji kongresów, konferencji i seminariów naukowych, praca magisterska, Katedra Geografii Miast i Turyzmu UŁ. 
B u r z y k B., 1993, Turystyczno-wypoczynkowa funkcja Lasu Lagiewnickiego, praca magisterska, Katedra Geografii Miast i Turyzmu UŁ.

C i c h o ń s k a J., 1995, Wartość turystyczna ulicy Piotrkowskiej w Eodzi, praca magisterska, Katedra Geografii Miast i Turyzmu UL.

C z a pli ńs k i Z., 1996, Wybrane ośrodki jeździeckie: Jantar, Stajnia pod Dzwonkami, Łódzki Klub Jeździecki jako tereny turystyki i rekreacji dla mieszkańców Łodzi i okolic, praca magisterska, Katedra Geografii Miast i Turyzmu UŁ.

D e 1 a g M., 1996, Funkcja turystyczna lódzkiego oddzialu PBP „Orbis” Sp. z o.o. i hotelu Grand Orbis s.a. w Lodzi, praca magisterska, Katedra Geografii Miast i Turyzmu UL.

D e n y s - S k u p i e ń s k a K., 1997, Funkcja poznawcza wycieczek szkolnych organizowanych przez biuro turystyczne „Panorama”, praca magisterska, Katedra Geografii Miast i Turyzmu UŁ.

G n a tow s k a A., 1996, Funkcja wypoczynkowa parku im. A. Mickiewicza w Lodzi, praca magisterska, Katedra Geografii Miast i Turyzmu Ut.

G w a de r a M., 1996, Turystyka $i$ wypoczynek pracowników ŁZPB im. Obrońców Pokoju „Uniontex" s.a., praca magisterska, Katedra Geografii Miast i Turyzmu UL.

K e g I e r D., 1990, Wypoczynek urlopowy rzemieślników Lodzi, praca magisterska, Katedra Geografii Miast i Turyzmu Ut.

K o fo d z i e j c z y k M., 1997, PT „Lódż” Centrum Ushug Turystycznych jako organizator turystyki $i$ wypoczynku mieszkańców Lodzi $i$ województwa, praca magisterska, Katedra Geografii Miast i Turyzmu UŁ.

K r ó I a k T., 1985, Funkcja wypoczynkowa Parku Kultury $i$ Wypoczynku w Lodzi, praca magisterska, Katedra Geografii Miast i Turyzmu UL.

L e s s m a n P., 1994, MOSiR „, Malinka" jako obszar wypoczynkowy dla mieszkańców Lódzkiej Aglomeracji Miejskiej, praca magisterska, Katedra Geografii Miast i Turyzmu UŁ.

L e w a n d o w s k i R., 1993, Wędkarstwo jako forma turystyki kwalifikowanej mieszkańców aglomeracji lódzkiej, praca magisterska, Katedra Geografii Miast i Turyzmu UŁ.

M a t y s i a k I., 1996, Funkcja turystyczno-kulturalna tódzkich palaców pofabrykanckich, praca magisterska, Katedra Geografii Miast i Turyzmu UŁ.

M i ą z e k - K a j k o w s k a M., 1988, Struktura przestrzenna i formy wypoczynku urlopowo-wakacyjnego i sobotnio-niedzielnego osiedla im. S. Batorego $w$ Lodzi, praca magisterska, Katedra Geografii Miast i Turyzmu UŁ.

M i c h a l a k A., 1998, Turystyka i wypoczynek mieszkańców osiedla „Pojezierska” $w$ Lodzi, praca magisterska, Katedra Geografii Miast i Turyzmu UŁ.

N i e d ź w i e c k a K., 1994, Miejski Ośrodek Sportu i Rekreacji jako tereny wypoczynku letniego mieszkańców Lodzi na przykladzie Stawów Stefańskiego i Stawów Jana, praca magisterska, Katedra Geografii Miast i Turyzmu UŁ.

N u r c z y ń s k i P., 1996, Funkcja kulturalno-wypoczynkowa tódzkich kin, praca magisterska, Katedra Geografii Miast i Turyzmu UŁ.

P a w I a k M., 1990, Wyjazdy wycieczkowe organizowane przez zaktady pracy jako forma wypoczynku mieszkańców, praca magisterska, Katedra Geografii Miast i Turyzmu Ut.

R o g a Is k i W., 1995, Weryfikacja zagranicznej oferty turystycznej PT ,Grand Tour" w sezonie letnim 1994 r. przez mieszkańców Lodzi, praca magisterska, Katedra Geografii Miast i Turyzmu Ut.

S a $1 \mathrm{t}$ a r s k a M., 1991, Wyjazdy zagraniczne mieszkańców Lodzi w 1990 r. (z wybranych biur podróży), praca magisterska, Katedra Geografii Miast i Turyzmu UL.

S t e p c z u k A., 1997, Rola i znaczenie tódzkich placówek muzealnych, praca magisterska, Katedra Geografii Miast i Turyzmu UŁ.

S z a r k o M., 1997, Wartość turystyczna zespolu fabryczno-rezydencjonalnego Karola Scheiblera „Księży Mlyn” w Lodzi, praca magisterska, Katedra Geografii Miast i Turyzmu UL.

S z c z e g i e 1 s k a M., 1989, Zagospodarowanie czasu wolnego pracowników ZPDz. „Olimpia" w Łodzi, praca magisterska, Katedra Geografii Miast i Turyzmu UŁ. 
S z y m a ń s k a A., 1995, Model turystyki i wypoczynku mieszkańców osiedla Radogoszcz Zachód w Łodzi, praca magisterska, Katedra Geografii Miast i Turyzmu UŁ.

T o m c zy k I., 1997, Wartość turystyczna dawnego zespolu fabryczno-rezydencjonalnego Izraela Poznańskiego $w$ Lodzi, praca magisterska, Katedra Geografii Miast i Turyzmu UŁ.

W a I b o r s k a E., 1995, Turystyka i wypoczynek uczniów XXV Liceum Ogólnoksztatcqcego w Lodzi, praca magisterska, Katedra Geografii Miast i Turyzmu UL.

W i t k o w s k a K., 1995, Percepcja przestrzeni turystycznej Lodzi przez jej mieszkańców, praca magisterska, Katedra Geografii Miast i Turyzmu UŁ.

Z m y s ł o w s k a E., 1994, Turystyka $i$ wypoczynek mieszkańców osiedla Stare Chojny w Lo$d z i$, praca magisterska, Katedra Geografii Miast i Turyzmu UL.

Z e b r o w s k a A., 1996, Obraz turystycznej Lodzi w świetle analizy zawartości treści przewodników, praca magisterska, Katedra Geografii Miast i Turyzmu Ut.

Mgr Elżbieta Paradowska

Katedra Geografii Miast i Turyzmu

Wplynęlo:

Uniwersytet Łódzki

al. Kościuszki 21

90-418 Łódź

Jerzy Wyrzykowski

SPRAWOZDANIE Z I MIĘDZYNARODOWEGO KONGRESU

NAUKOWEGO pt. ,TURYSTYKA I KULTURA

DLA HARMONIJNEGO ROZWOJU" (ATENY, 19-21.05.1998)

LE COMPTE-RENDU DU I. CONGRÈS SCIENTIFIQUE

INTERNATIONAL INTITULÉ: „LE TOURISME ET LA CULTURE

POUR LE DÉVELOPPEMENT HARMONIEUX",

ATHÈNES, 19-21.05.1998

REPORT FROM THE Ist INTERNATIONAL SCIENTIFIC CONGRESS 'TOURISM AND CULTURE FOR HARMONIOUS DEVELOPMENT' (ATHENS, 19th-21st MAY 1998)

W dniach 19-21 maja 1998 r. w Atenach odbył się Kongres Naukowy poświęcony problematyce turystyki i kultury jako dwubiegunowego systemu służącego harmonijnemu rozwojowi. Kongres był okazją do zaprezentowania dorobku teoretycznego i praktycznego przedstawicieli różnych dyscyplin naukowych w tym w zakresie i w zamyśle organizatorów - początkiem dalszej mię- 